\title{
Network analysis of nursing publications in the COVID-19 era
}

\author{
Hatice Öntürk ${ }^{1}$, Emine Kübra Dindar Demiray ${ }^{2}$, Sevil Alkan ${ }^{3}$ \\ ${ }^{1}$ Nursing Department, School of Health Sciences, Bitlis Eren University, Bitlis, Turkey \\ ${ }^{2}$ Department of Infectious Diseases and Clinical Microbiology, Bitlis State Hospital, Bitlis, Turkey \\ ${ }^{3}$ Department of Infectious Diseases and Clinical Microbiology, Faculty of Medicine, Çanakkale Onsekiz Mart University, Çanakkale, Turkey
}

Received: 2021-05-09.

Accepted: 2021-06-21

This work is licensed under a Creative Commons Attribution 4.0 International License

J Clin Med Kaz 2021; 18(4):27-31

Corresponding author:

Sevil Alkan.

E-mail: s-ewil@hotmail.com;

ORCID: 0000-0003-1944-2477.

\section{Abstract}

Objective: COVID 19, which affects all areas of life, is perhaps one of the most studied subjects in the field of medicine, and the number of global publications is increasing day by day. The nursing profession and practices have also been directly affected by this rapid stream of broadcasts. The study was planned to examine in detail the studies on 'COVID and nursing' and to guide the studies to be planned in the future.

Material and methods: In our study, the Web of Science (WOS) database was scanned to search for publications with topics of 'nursing' or 'SARS COV-2', 'nurse' and 'COVID 19', 'nursing' and 'COVID 19' and 'nurse' and 'SARS COV-2' were reviewed.

Results: A total of 562 publications were included in the study. The country with the highest number of publications was the United States (32\%). While 388 (69\%) of the publications were cited, it was determined that 174 (31\%) of them were not cited at all. The average number of citations of these 562 publications was found to be 3.28. The $\mathrm{H}$ index reached by these publications, which were cited 1.843 times in total, was found to be 17. The most cited journal of ours is; It was the New England Journal of Medicine (369 citations).

Conclusion: As in every field of publication, the pandemic has been effective in the field of nursing, and the number of publications has increased globally. Considering the citation rates of the publications, it was determined that there is a wide field of study in this field.

Key words: network analysis, nursing, COVID-19, nurse, publications

\section{Introduction}

The coronavirus disease (COVID 19), which has rapidly spread all over the world since the first case appeared in December 2019 and was declared a pandemic by the World Health Organization (WHO) in March 2020, has changed our lives globally [1].

Currently, there is no definitive treatment for COVID-19, but some vaccines for (COVID-19) prevention have been permitted and started to be used all over the world. However, the only proven method of management in combating the disease is prevention, isolation and supportive care. For these reasons, the nursing burden, which plays a major role in supportive care, decreases. Pandemic; it has led to rapid changes in almost every field from intensive care, clinical care, home health, and wound care nursing [2,3].

COVID 19, which affects life on it, is one of the most studied topics in the field of medicine, and the number of global publications is increasing day by day. The nursing profession and practices have also been affected by this rapid stream of broadcasts. The aim of this study is to examine studies about 'COVID and nursing' and to guide the studies to be planned in the future.

\section{Material and methods}

Bibliometric analysis method [4], which includes the application of mathematical and statistical methods to scientific publications, is the cornerstone of modern literature [5]. Bibliometric analysis is the determination of the relationships between publications numerically by examining the publications made individually or institutionally in certain periods and in certain regions [6].

In our study, the Web of Science (WOS) database (https://www.webofknowledge.com) was scanned to search for publications until January 21, 2021. WOS database is a database where the articles of the world's most prestigious journals is accessed. The data obtained in this study were analyzed to present various bibliometric 
indicators. We used the visualization tool using the maps VOS viewer program (VOS viewer). Hirsch $(\mathrm{H})$ index and impact factor (IF) of the publishing journal were used as indicators of the impact of the publications.

In the study, publications containing the keywords: 'COVID 19 ' and 'nursing' or 'COVID 19' and 'nurse' 'SARS COV-2' and 'nursing' or 'SARS COV-2' and 'nurse' were examined.

Among the obtained studies, research articles, reviews, case reports, letters to the editor were included in the research. The links of the citations between the date the publications were written, the publication language, the number of citations, the field of research, the name of the journal, the country where the publication was made and the countries cited were examined.

\section{Results}

The research data were obtained from the WOS database. In the study, it was found that there were 562 publications in the WOS database search made with keywords as a result of the search. The first publication was written in the pre-pandemic era in 2019. Looking at the years of publication; It was determined that 1 articles in 2019, 528 articles in 2020 and 33 articles until 21 January 2021 were published.

Considering the distribution of the publications by months, it was determined that the increase in the number of publications that started in March 2020 reached its peak in October 2020. The distribution by months is given in Figure 1.

Figure 1 - Distribution of publications by months

\section{Publication month}

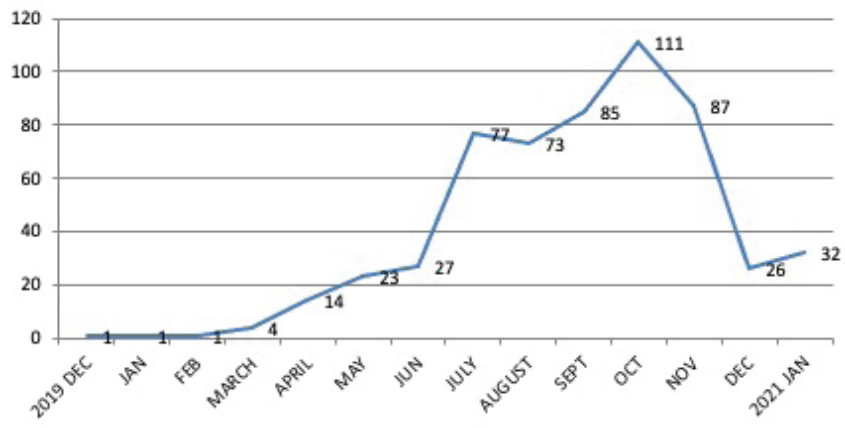

Considering the distribution of the published documents; it was determined that the most article type $(55.5 \%)$ in the subject area of our study.

When the broadcast language of the publications is examined; 531 were in English, 12 in Spanish, 6 in German, 3 in Portuguese, Norwegian, Italian and French, and one in Turkish languages.

Table 1

\begin{tabular}{|l|l|l|}
\hline Document Types & Records $(\mathrm{n}=562)$ & $\%$ \\
\hline Article & 312 & 55.516 \\
\hline Editorial material & 151 & 26.868 \\
\hline Early access & 86 & 15.302 \\
\hline Letter & 67 & 11.922 \\
\hline Review & 18 & 3.203 \\
\hline Meeting abstract & 7 & 1.246 \\
\hline Correction & 4 & 0.712 \\
\hline News item & 3 & 0.534 \\
\hline
\end{tabular}

The 3 most published workspaces of publications; Nursing (46.8\%), Geriatrics gerontology (14.4\%) and General internal medicine (12.8\%). Other fields of study are given in Table 2.

Table 2 Research Areas

\begin{tabular}{|l|l|l|}
\hline Research Areas & $\mathrm{n}$ & $\%$ \\
\hline Nursing & 263 & 46.797 \\
\hline Geriatrics gerontology & 81 & 14.413 \\
\hline General internal medicine & 72 & 12.811 \\
\hline Psychiatry & 62 & 11.032 \\
\hline Public environmental occupational health & 52 & 9.253 \\
\hline Health care sciences services & 26 & 4.626 \\
\hline Environmental sciences ecology & 21 & 3.737 \\
\hline Business economics & 15 & 2.669 \\
\hline Psychology & 12 & 2.135 \\
\hline Education educational research & 11 & 1.957 \\
\hline Infectious diseases & 11 & 1.957 \\
\hline Oncology & 11 & 1.957 \\
\hline Neurosciences neurology & 10 & 1.779 \\
\hline Cardiovascular system cardiology & 7 & 1.246 \\
\hline Pharmacology pharmacy & 6 & 1.068 \\
\hline Social sciences other topics & 5 & 0.89 \\
\hline Pediatrics & 4 & 0.712 \\
\hline Research experimental medicine & 4 & 0.712 \\
\hline Science technology other topics & 4 & 0.712 \\
\hline Integrative complementary medicine & 3 & 0.534 \\
\hline Rehabilitation & 3 & 0.534 \\
\hline Respiratory system & 3 & 0.534 \\
\hline Endocrinology metabolism & 2 & 0.356 \\
\hline Hematology & 2 & 0.356 \\
\hline Immunology & 2 & 0.356 \\
\hline Microbiology & 2 & 0.356 \\
\hline Obstetrics gynecology & 2 & 0.356 \\
\hline Public administration & & 0.356 \\
\hline Social work & 0.356 \\
\hline Veterinary sciences & 2 & \\
\hline Other* & 2.356 \\
\hline & 2 & \\
\hline & 2 & \\
\hline
\end{tabular}

* Workspaces which one publication is available, *Anesthesiology, Cell biology, Communicatıon, Criminologypenology, Dentistry oral surgery medicine, Emergency medicine, Engineering, Life sciences biomedicine thertopics, Medical ethics, Nutrition dietetics, Substance abuse, Surgery, Toxicology, Tropical medicine

Considering the distribution of the countries where the publications were made, it was determined that the most publications in the field of our study were made from the United States of America (32\%), China (15\%) and England $(7.3 \%)$. The distribution of the 20 countries with the highest number of publications is given in Table 3 .

While $388(69 \%)$ of the publications were cited, it was determined that $174(31 \%)$ were not cited at all. The average number of citations of these 562 publications was found to be 3.28. The $\mathrm{H}$ index reached by these publications, which were cited 1.843 times in total, was found to be 17 . The top 3 journals cited about our most work; New England Journal of Medicine (369 citations), MMWR-Morbidity And Mortality Weekly Report (324 citations) and Journal of ClinicalNursing (170 
Distribution of publications by countries.

\begin{tabular}{|l|l|l|}
\hline Countries & $\mathrm{n}$ & $\%$ \\
\hline USA & 181 & 32.206 \\
\hline Peoples R China (PRC) & 89 & 15.836 \\
\hline England & 41 & 7.295 \\
\hline Spain & 39 & 6.94 \\
\hline Australia & 35 & 6.228 \\
\hline Italy & 21 & 3.737 \\
\hline Brazil & 19 & 3.381 \\
\hline Canada & 19 & 3.381 \\
\hline Turkey & 18 & 3.203 \\
\hline Scotland & 15 & 2.669 \\
\hline France & 14 & 2.491 \\
\hline Switzerland & 13 & 2.313 \\
\hline Germany & 12 & 2.135 \\
\hline Iran & 12 & 2.135 \\
\hline Netherlands & 12 & 2.135 \\
\hline Saudi Arabia & 11 & 1.957 \\
\hline India & 10 & 1.779 \\
\hline Taiwan & 9 & 1.601 \\
\hline Ireland & 8 & 1.423 \\
\hline Japan & 8 & 1.423 \\
\hline
\end{tabular}

*USA: The United States of America

citations). The number of citations, the number of publications and the average number of citations of the first 15 journals with the highest number of citations are given in Table 4 .

Table 4

Most Cited Journals and Number of Citations

\begin{tabular}{|c|c|c|c|}
\hline Journal & Citation & PublicationNumber & AverageCitation \\
\hline \begin{tabular}{|l|} 
New England Journal \\
Of Medicine \\
\end{tabular} & 369 & 3 & 125 \\
\hline $\begin{array}{l}\text { MMWR-Morbidity } \\
\text { and Mortality Weekly } \\
\text { Report }\end{array}$ & 324 & 8 & 40,5 \\
\hline \begin{tabular}{|l|} 
Journal of Clinical \\
Nursing
\end{tabular} & 170 & 24 & 97 \\
\hline \begin{tabular}{|l|}
$\begin{array}{l}\text { Journal of Nursing } \\
\text { Management }\end{array}$ \\
\end{tabular} & 111 & 14 & 62,5 \\
\hline $\begin{array}{l}\text { Journal of the } \\
\text { American Geriatrics } \\
\text { Society }\end{array}$ & 93 & 18 & 55,5 \\
\hline \begin{tabular}{|l|} 
Journal of the \\
American Medical \\
Directors Association \\
\end{tabular} & 80 & 27 & 53,5 \\
\hline Critical Care & 61 & 5 & 12,2 \\
\hline $\begin{array}{l}\text { Journal of Pain } \\
\text { and Symptom } \\
\text { Management }\end{array}$ & 59 & 5 & 11,8 \\
\hline $\begin{array}{l}\text { JAMA-Journal of The } \\
\text { American Medical } \\
\text { Association }\end{array}$ & 42 & 6 & 7 \\
\hline Lancet Psychiatry & 31 & 1 & 31 \\
\hline \begin{tabular}{|l|} 
Archives of Clinical \\
Infectious Diseases
\end{tabular} & 26 & 1 & 26 \\
\hline \begin{tabular}{|l|}
$\begin{array}{l}\text { International Journal } \\
\text { of NursingStudies }\end{array}$ \\
\end{tabular} & 24 & 7 & 3,43 \\
\hline $\begin{array}{l}\text { Nurse Education In } \\
\text { Practice }\end{array}$ & 22 & 6 & 3,67 \\
\hline Journal Of Infection & 22 & 5 & 4,4 \\
\hline $\begin{array}{l}\text { International Journal } \\
\text { of Environmental } \\
\text { Research and Public } \\
\text { Health } \\
\end{array}$ & 17 & 16 & 16,5 \\
\hline
\end{tabular}

53 of the publications from 72 countries have at least 1 reference, and the number of countries citing each other was 46. The citation maps of these 46 countries are presented in Figure 2.

Figure 2 - Network visualization map prepared according to citation numbers among countries with at least one publication and citations on COVID 19, SARS COV-2, Nursing and Nurses. * Lines connecting countries are indicative of citations. Countries represented by larger circle size or font size have relatively more articles.

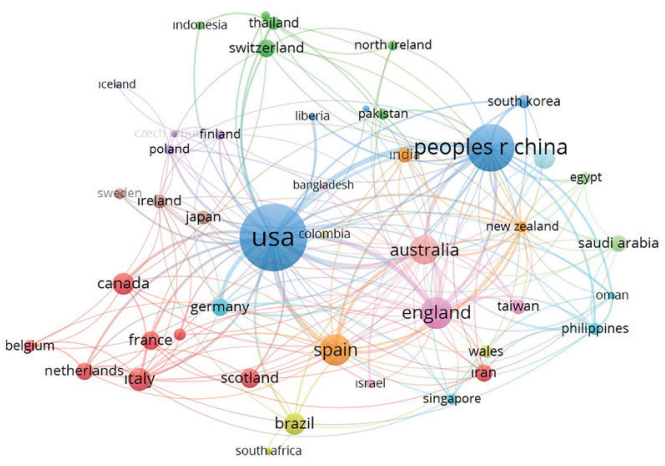

It is the keywords of only $308(67.6 \%)$ of the publications, and the visualized versions of the keywords are presented in Figure 3.

Figure 3 - The density map of the keywords of the publications that are repeated at least 3 times about the words COVID-19, SARS COV-2, Nursing and Nurse.

* Lines connecting words are indicative of keywords that are together. There are relatively more words represented by larger circle size or font size.

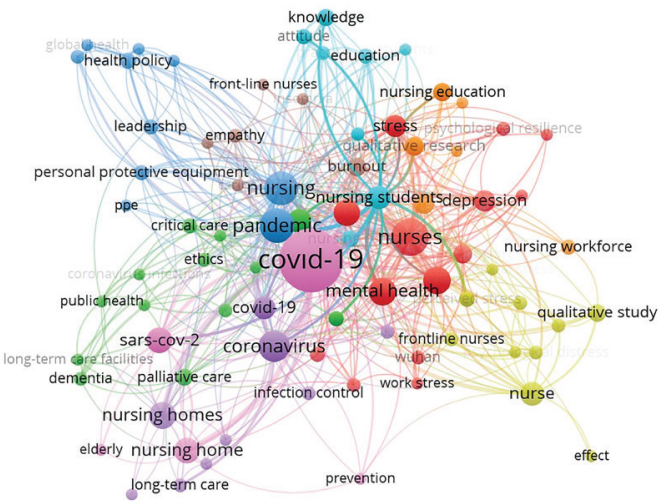

Figure 4 - The density map of the keywords of the publications about the words COVID-19, Sars Cov-2, Nursing and Nurse repeated at least 3 times.

* Lines connecting words are indicative of keywords that are together. There are relatively more words represented by larger circle size or font size.

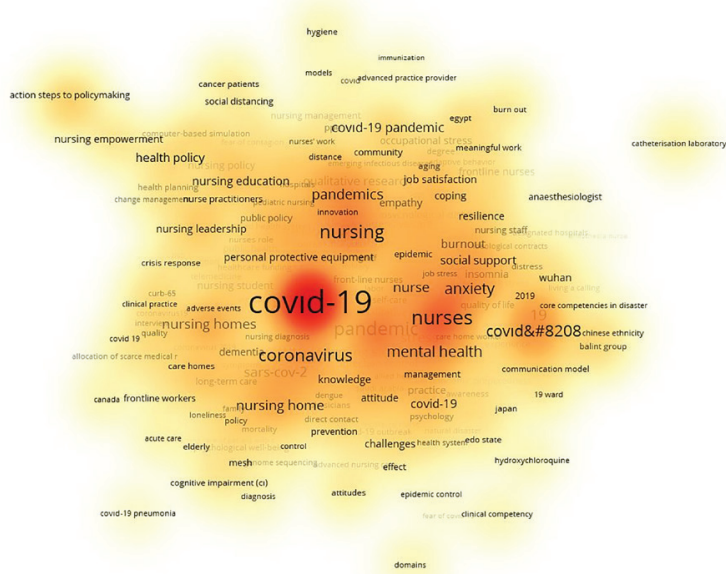




\section{Discussion}

COVID-19, which was first seen in Wuhan, China and spread to the whole world in a short time and accepted as a pandemic by WHO, caused great changes in the world of science as well as in all areas of life [7]. The study was carried out to analyze the scientific studies conducted on the nursing profession, which is the cornerstone of patient care during the pandemic process.

After the announcement of COVID-19 as a pandemic in March 2020, scientific activities in the academic field have rapidly become prone to this issue [7]. In our study, when we look at the distribution of the publications by months, it was determined that the increase in the number of publications that started in March 2020 reached its peak in October 2020. There is no cure for COVID 19 yet. The fact that supportive treatment and nursing care is one of the most important issues signals that more academic research will be conducted on this subject.

Since the day it emerged, the changes it has brought about in the lives of individuals have continued to increase day by day. Changes experienced in many areas such as technology, economy, tourism, education, social and culture all over the world also show their effects in the world of science [8]. Studies in science, health and social fields have also rapidly turned its direction to the pandemic that has affected the world.

Due to the rapid changes in the health sector, pandemic studies have taken the center of scientific research in the field of health. Studies in medicine, nursing, and pharmacy have begun to contribute significantly to the scientific world. In addition, when the studies conducted are examined, it is seen that there are studies that investigate the roles and functions of the nursing profession, the physical, mental and social lives of nurses working in key units such as intensive care and emergency clinics, and the effect of the pandemic on the education of students who receive health education, including nursing [9]. The pandemic process has pointed out that the nursing profession is a great power that changes and affects health. It has been demonstrated that the profession was born out of a social need and was a key part of the care role in all epidemics in the historical process [10-12].

Throughout the pandemic process, nurses, who take the role of close contact and care with cases in units that require complex care, both in intensive care and in units diagnosed with COVID 19, constituted an important part of the process [12]. Nurses working at the front because of their duties and responsibilities have been the occupational group that spent the longest time with the patient and had to come into frequent contact with the patients due to their duties. The COVID 19 process has highlighted the need for nurses, the roles and responsibilities of nurses in patient care, and the need for scientific research in this field [13].

The study was carried out on the WOS database, and during the COVID 19 process, it was carried out in order to examine the publications in the field of nursing and to observe the general picture by gaining visualization. In the study, a total of 14 months of publications and scientific studies were examined between December 2019 and January 2021, and the analysis in terms of what the publications were, when they were made, the journal in which they were published, the areas where the highest number of publications were made, the number of citations received by the journals, the language of the publication, the countries where the publications were made. Numerous publications in the nature of similar bibliometric analysis have been reported in the literature [14-16].

The distribution of the number of studies by months varies according to the course of the pandemic. While the number of studies was quite limited in the months when the number of patients gradually increased and restrictions were intense, the number increased in the summer and early autumn, when the pandemic's course towards positive was felt. However, a decrease is observed in studies in the last spring and winter months, when the number of cases increased in our country and worldwide. This result is thought to be related to the pace of work of the intense pandemic period [17-19].

When the types of work are examined; It is understood that the first place is the article, the type of Editorial material, Early Access, Letter, Review, Meeting abstract, News item and Correction type studies. Similar types of studies have been found in the literature $[16,20]$. In a similar bibliometric study in which subject analyzes were also made, peer-reviewed journal articles were found to be the most common type of study with a rate of $88 \%$. In the same study, studies of original article type, letters to the editor, reviews, conference papers, case presentations, book chapters are followed [21]. Similar studies have been found in the literature [21-23].

When the publications are examined in terms of language in the study; 531 were in English, 12 in Spanish, 6 in German, 3 in Portuguese, Norwegian, Italian and French, and one in Turkish. When the working languages are examined, it is seen that there is only one study written in Turkish, while there are 531 studies in English. In some languages, no studies were found.

When the study fields of the publications are examined, it is seen that the 3 most published worksheets are; Nursing (46.8\%), Geriatricsgerontology (14.4\%) and General internal medicine $(12.8 \%)$ (Table 2). Other fields of study are given in Table 2. When the working areas of the studies are examined, it is seen that there are mostly publications on care and nursing services. In Covid patients, individual self-care needs, special oral care and skin care, effective breathing, hydration status, adequate nutrition, mental and social support services are considered to be effective in the healing process and therefore there is a tendency to these areas. Similarly, many publications were found in the literature [16-20].

When the distribution of all studies by country was examined, it was determined that the most publications were made from the United States, which has the highest number of cases globally [6]. It is seen that $181(32 \%)$ of the studies carried out during 2020 belong to the USA. In addition, $89(15 \%)$ articles were published from China, which is declared the homeland of COVID 19 in the second place. Turkey this ranking in $18(3 \%)$ and the number of broadcast ranks 9 th among the world countries.

According to the analysis, $388(69 \%)$ of the publications were cited while 174 (31\%) were not cited at all. The average number of citations of these 562 publications was found to be 3.28. The $\mathrm{H}$ index reached by these publications, which were cited 1.843 times in total, was found to be 17 . Top 3 journals cited about our most work; New England Journal of Medicine (369 citations), MMWR-Morbidity And Mortality Weekly Report (324 citations) and Journal of ClinicalNursing (170 citations). When the literature is examined, studies that draw attention to the number and quality of citations of scientific publications have been found [24,25]. The most cited articles were about the nursing facility, work stress among nurses, burnout frequency, psychological - mental health and COVID-19 anxiety.

Many studies have been conducted on the subject of getting citations, which is one of the indicators of the quality and prestige of the journal, the subject of the cited study and the cited author. When the literature was examined, similar studies were found that examined the number of citations in journals and the relationships between cited journals [16,24,25]. 


\section{Conclusion}

The pandemic has increased in number of publications globally, as a result of which there have been many publications in the field of nursing. Considering the citation rates of the publications in this field, it can be said that this field is a wide field of study. In future studies, it can be planned as a broadbased study that includes analysis of the author profile, number of authors, study topics, study dates and citation status.

\section{Limitations of the study}

In the study, analyzes were made using the WOS database. However, as new articles are added to WOS every day due to the increasing number of publications due to the pandemic, the data may reflect the information until the day of analysis.

Disclosures: There is no conflict of interest for all authors. Acknowledgements: None.

Funding: None.

\section{References}

1. https://covid19.who.int/ Internet. [Accessed: 25 January 2021]

2. Sharma SK, Nuttall C, Kalyani V Hemlata. Clinical nursing care guidance for management of patient with COVID-19. J Pak Med Assoc. 2020; 70(3)(5):S118-S123. doi: 10.5455/JPMA.29. PMID: 32515397.

3. Bambi S, Iozzo P, Lucchini A. New Issues in Nursing Management During the COVID-19 Pandemic in Italy. Am J Crit Care. 2020; 29(4):e92-e93. doi: 10.4037/ajcc2020937. PMID: 32467964.

4. Pritchard A. Statistical bibliography or bibliometrics? J Document. 1969; 25(4):348-349.

5. Bornmann L. Measuring impact in research evaluations: a thorough discussion of methods for, effects of, and problems with impact measurements. Higher Educ. 2017; 73(5):775-787. https://doi.org/10.1007/s10734-016-9995-x

6. https://cabim.ulakbim.gov.tr/bibliyometrik-analiz/bibliyometrik-analiz-sikca-sorulan-sorular/ (Accessed date: 04.01.2021)

7. Kürtüncü M, Kurt A. COVID-19 PANDEMISİ DÖNEMINDE HEMŞIRELIK ÖĞRENCILERININ UZAKTAN EĞiTIM KONUSUNDA YAŞADIKLARI SORUNLAR. Avrasya Sosyal ve Ekonomi Araştırmaları Dergisi. 2020; 7(5):66-77.

8. Huang C, Wang Y, Li X, Ren L, Zhao J, Hu Y, et al. Clinical features of patients infected with 2019 novel coronavirus in Wuhan, China. Lancet. 2020; 395(10223):497-506. doi: 10.1016/S0140-6736(20)30183-5.

9. Brooks SK, Smith LE, Webster RK, Weston D, Woodland L, Hall I, Rubin GJ. The impact of unplanned school closure on children's social contact: rapid evidence review. Euro Surveill. 2020; 25(13):2000188. doi: 10.2807/1560-7917.ES.2020.25.13.2000188. PMID: 32265006; PMCID: PMC7140596.

10. Smith GD, Ng F, Ho Cheung Li W. COVID-19: Emerging compassion, courage and resilience in the face of misinformation and adversity. J Clin Nurs. 2020; 29(9-10):1425-1428. doi: 10.1111/jocn.15231.

11. Dağhan, Ş. Halk sağlı̆̆ hemşireliği felsefesiyle hemşire olmak" anlamı nedir? Dokuz Eylül Üniversitesi Hemşirelik Yüksekokulu Elektronik Derg. 2017; 10(2):107-112.

12. Choi KR, Skrine Jeffers K, Cynthia Logsdon M. Nursing and the novel coronavirus: Risks and responsibilities in a global outbreak. J Adv Nurs. 2020; 76(7):1486-1487. doi: 10.1111/jan.14369.

13. Jackson D, Bradbury-Jones C, Baptiste D, Gelling L, Morin K, Neville S, et al. Life in the pandemic: Some reflections on nursing in the context of COVID-19. J Clin Nurs. 2020; 29(13-14):2041-2043. doi: 10.1111/jocn.15257.

14. Yanbing S, Ruifang Z, Chen W, Shifan H, Hua L, Zhiguang D. Bibliometric analysis of Journal of Nursing Management from 1993 to 2018. J NursManag. 2020; 28:317-331. https://doi.org/10.1111/jonm.12925

15. Barragán Martín AB, Molero Jurado MDM, Pérez-Fuentes MDC, Simón Márquez MDM, Sisto M, Gázquez Linares JJ. Published Research on Burnout in Nursing in Spain in the Last Decade: Bibliometric Analysis. Healthcare (Basel). 2020; 8(4):478. doi: 10.3390/healthcare8040478.

16. Kantek F, Yesilbas H. Conflict in nursing studies: A bibliometric analysis of the top 100 cited papers. J Adv Nurs. 2020; 76(10):2531-2546. doi: 10.1111/jan.14463.

17. Morin KH. Nursing education after COVID- 19: Same or different? Journal of Clinical Nursing. 2020; 29:3117-3119. https:// doi.org/10.1111/jocn.15322

18. Christopher R, de Tantillo L, Watson J. Academic caring pedagogy, presence, and Communitas in nursing education during the COVID-19 pandemic. Nursing Outlook. 2020;S0029-6554(20)30620-5. Advance online publication

19. Dewart G, Corcoran L, Thirsk L, Petrovic K. Nursing education in a pandemic: Academic challenges in response to COVID-19. Nurse Education Today. 2020; 92:104471. https://doi.org/10.1016/j.nedt.2020.104471

20. Huang YL, Ho YS, Chuang KY. Bibliometric analysis of nursing research in Taiwan 1991-2004. J Nurs Res. 2006; 14(1):75-81. doi: 10.1097/01.jnr.0000387564.57188.b4. PMID: 16547908.

21. Dardas LA, Sawair FA, Nabolsi M, Simmons LA. Nursing research in the Arab Region: A bibliometric analysis. Int J Nurs Pract. 2019; 25(3):e12716. doi: 10.1111/ijn.12716.

22. Taşkaya S, Aksoy A. A bibliometric analysis of workplace incivility in nursing. J Nurs Manag. 2020. doi: 10.1111/jonm.13161. Epub ahead of print. PMID: 32964566.

23. Waldrop J, Carter-Templeton H, Nicoll LH. Bibliometric Impact Analysis for the Journal for Nurse Practitioners: 2015-2017. Comput Inform Nurs. 2020; 38(1):1-4. doi: 10.1097/CIN.0000000000000613. PMID: 31923005.

24. Železnik D, Blažun Vošner H, Kokol P. A bibliometric analysis of the Journal of Advanced Nursing, 1976-2015. J Adv Nurs. 2017; 73(10):2407-2419. doi: 10.1111/jan.13296.

25. Bulut E, Dokur M, Basar E. The Top 100 Cited Articles on Ocular Trauma: A Bibliometric Analysis. Eur J Ther. 2020; 26(4):32231. https://doi.org/10.5152/eurjther.2020.19115

26. Giménez-Espert MDC, Prado-Gascó VJ. Bibliometric analysis of six nursing journals from the Web of Science, 2012-2017. J Adv Nurs. 2019; 75(3):543-554. doi: 10.1111/jan.13868. 